\title{
Utilisation of Oil Palm Ash in Foamed Concrete
}

\author{
H. Awang ${ }^{1}$, M. Z. Al-Mulali ${ }^{2}$, H.P.S. Abdul Khalil ${ }^{3}$, Z. S. Aljoumaily ${ }^{4}$ \\ ${ }^{1,2,4}$ School of Housing, Building and Planning, Universiti Sains Malaysia, Penang, 11800, Malaysia \\ ${ }^{3}$ School of Industrial Technology, Universiti Sains Malaysia, Penang 11800, Malaysia
}

\begin{abstract}
This study is a part of an on-going research examining the properties of foam concrete when replacing the cement with semi-processed Oil Palm Ash (OPA). Replacements range from $25 \%$ to $65 \%$ were used for a mix having the mix ratio of (1:2:0.45) and having the target density of $1300 \mathrm{~kg} / \mathrm{m}^{3}$. All mixes were tested for their strength using the compressive, splitting tensile and flexural strengths up to the age of 28 days. Results show that a $25 \%$ replacement level exhibited higher compressive and splitting tensile strength than that of the control mix at the age of 28 days. However, the same replacement level exhibited a close strength to that of the control mix when tested for the flexural strength at the same age.
\end{abstract}

\section{Introduction}

Foam concrete, is a type of lightweight concrete. This type of concrete is a homogeneous material due to the absence of large aggregates when compared to conventional concrete. The most attractive properties that this type of concrete has are its self-compacting and self-levelling nature, flow-ability, its ability to be produced with very low densities [1] and its low weight leading to designing more economical supporting structures such as foundations, walls and floors [2]. Furthermore, foam concrete is considered to be an environmentally friendly product because it uses less natural resources and the ability to incorporate larger amounts of waste materials within its mix [3]. Such wastes include fly ash, rice husk ash and blast furnace slag. These by-products can possess pozzolanic properties that can enhance the characteristics of concrete further more. These pozzolanic materials are called Supplementary cementitious materials [4]. Oil palm ash has been introduced recently to be a pozzolanic material.

Oil palm Ash (OPA) or Palm Oil Fuel Ash (POFA) is a by-product produced by countries having a blooming palm oil industry such as Malaysia and Thailand. It is generated by the incineration of oil palm shell and palm oil empty fruit bunch at $800 \mathrm{C}^{\circ}$ to $1000 \mathrm{C}^{\circ}$ as a mean of heating up the mill's boilers instead of using conventional fuels. Due to this incineration process, ash is produced at about $5 \%$ by weight of the incinerated solid fuels [5]. The quantity of OPA produced in Malaysia alone is about 4 million tonnes a year [6].

OPA is a throw away product that is produced abundantly. Common practices for disposing of this by-product were either by tipping or dumping. Hence, the waste is either spread over the premises of the mill or dumped to fill in low economic value dumps or selected types of land such as swamplands, abandoned sand quarries [7]. These disposal methods were conducted without taking into consideration the surrounding environment or taking precautions to compact, cover and prevent the spreading of pollutants into the ground water levels [7]. In addition, due to its fine particles, OPA can 
be easily carried away by wind by that causing smog on a humid day [8]. Therefore, the utilisation of OPA in concrete production has a number of environmental benefits such as reducing the amount of OPA that is disposed of into landfills, reducing the amount of energy used and the emitted greenhouse gases when OPA is used to replace manufactured cement and the conservation of other natural resources when OPA is used as filler replacement. Therefore, a number of studies focused on the utilisation of OPA in the construction industry as a mean of recycling such a waste. OPA has been used as a binder or filler replacement in normal concrete [8,9,10], high strength concrete [11,12], mortar $[10,13]$ and aerated concrete $[14,15,16]$.

This study is a part of an on-going research studying the effects of semi-processed OPA on the properties of foam concrete when used as a cement replacement. It is common sense to utilise such a by-product into the manufacture of an environmentally friendly concrete in order to make it greener.

\section{Materials}

The cement used is a Type I cement which can be classified as MS 522 and complies with BS EN 196 of the British Standards. The cement is manufactured in Malaysia under the CIMA group and packed under the name (Blue Lion). Natural sand form a local river bed was used as the fine sand in this study. A sieve analysis was conducted on the sand and it fell into zone 3 according to BS 882: Part 2: 1973.

Oil palm ash was produced by the incineration of oil palm shell and empty fruit bunch by a nearby palm oil mill. The type of ash used has been incinerated at a temperature of $800 \mathrm{C}^{\circ}$. The OPA used in this study is the passing through a $300 \mu \mathrm{m}$ sieve. Tablel shows the chemical composition of both the cement and OPA used in this study. The OPA's chemical composition complies with a class F pozzolana according to ASTM C 618 [17].

The foaming agent is a protein based agent called (Noraite PA-1) which is manufactured in Malaysia. The foaming agent was diluted in water at a ratio of $(1: 30)$ by volume producing stable foam with a density range of $64 \mathrm{~kg} / \mathrm{m}^{3}$ to $68 \mathrm{~kg} / \mathrm{m}^{3}$. A super-plasticiser called (PS-1), also manufactured in Malaysia, is used with mixes containing OPA replacements. This additive is based on soluble salts of Polymeric Sulphonates. Table 2 shows the characteristics of this additive.

Table 1: Chemical composition of cement and OPA

\begin{tabular}{ccc}
\hline Chemical composition \% & Cement & OPA \\
\hline Silicon Dioxide $\left(\mathrm{SiO}_{2}\right)$ & 19.98 & 66.6411 \\
Aluminium Oxide $\left(\mathrm{Al}_{2} \mathrm{O}_{3}\right)$ & 5.17 & 3.8164 \\
Iron Oxide $\left(\mathrm{Fe}_{2} \mathrm{O}_{3}\right)$ & 3.27 & 3.6979 \\
Calcium Oxide $(\mathrm{CaO})$ & 63.17 & 5.2290 \\
Magnesium Oxide $(\mathrm{MgO})$ & 0.79 & 2.2866 \\
Sulphur Trioxide $(\mathrm{SO})$ & 2.38 & 0.4278 \\
Loss on $\mathrm{Ignition}_{3}(\mathrm{LOI})$ & 2.5 & 2.32 \\
$\mathrm{SiO}_{2}+\mathrm{Al}_{2} \mathrm{O}_{3}+\mathrm{Fe}_{2} \mathrm{O}_{3}$ & -- & 74.155 \\
\hline
\end{tabular}

Table 2: PS-1 Characteristics and typical composition

\begin{tabular}{cc}
\hline Chemical content & A mixture of sodium acids and glycol compounds \\
\hline Appearance & Brown to light brown coloured liquid \\
\hline Total Solids \% & 40 \\
\hline PH Solution & 7.5 to 8.0 \\
\hline Salt Content & Max. 5\% \\
\hline In-Soluble Materials & Negligible \\
\hline Chlorides as NACL & Nil \\
\hline
\end{tabular}




\section{Mixing Procedure}

A total of six mixes have been conducted in this part of this research. Each mix had the mix ratio of (1:2:0.45), a target density of $1300 \mathrm{~kg} / \mathrm{m}^{3}$ and a volume of $0.18 \mathrm{~m}^{3}$. The difference between target and wet density was fixed at $150 \mathrm{~kg} / \mathrm{m}^{3}$. Cement has been replaced by OPA at levels starting from $25 \%$ to $65 \%$. Super- plasticiser (PS-1) was added to the mixes containing OPA at a percentage of $1 \%$ by weight of cementation materials. The flow table taste was kept at a range between $22 \mathrm{~cm}$ and $24 \mathrm{~cm}$. Table 3 shows the mix proportion for the mixes conducted.

Table 3: Mix proportions

\begin{tabular}{ccccccccc}
\hline \multirow{2}{*}{ No. } & Mix & \multicolumn{9}{c}{ Mix Proportions (kg) } & Slump \\
\cline { 3 - 8 } & Symbol & OPC & OPA & Sand & Water & PS-1 & W/C & (cm) \\
\hline 1 & CC & 74.6 & -- & 149.2 & 25.07 & - & 0.45 & 22.0 \\
2 & OPA25 & 55.95 & 18.65 & 149.2 & 26.44 & 0.746 & 0.45 & 22.0 \\
3 & OPA35 & 48.49 & 26.11 & 149.2 & 26.58 & 0.746 & 0.45 & 22.5 \\
4 & OPA45 & 41.03 & 33.57 & 149.2 & 27.33 & 0.746 & 0.45 & 23.0 \\
5 & OPA55 & 33.57 & 41.03 & 149.2 & 27.47 & 0.746 & 0.45 & 23.5 \\
6 & OPA65 & 26.11 & 55.95 & 149.2 & 32.24 & 0.746 & 0.45 & 23.0 \\
\hline
\end{tabular}

\section{Testing Procedures}

All specimens were de-moulded after $24 \mathrm{hrs}+2 \mathrm{hrs}$ from mixing. Afterwards the specimens were wrapped with polythene wrapping and kept until the day of testing [18]. Before $24 \mathrm{hrs}$ of the testing date, specimens were kept in an oven at a temperature of $105 \mathrm{C}^{\circ} \pm 2 \mathrm{C}^{\mathrm{o}}$ then they would be taken out, weighed, left to cool down then tested. Tests were conducted at the age of 7, 14 and 28 days. Compressive strength, splitting tensile strength and flexural strength were examined for all mixes. For compressive strength, a $100 \mathrm{~mm}$ cube is used and the mean of three cubes was taken as the reading for each age. For the splitting tensile strength, a cylinder having a length of $200 \mathrm{~mm}$ and a diameter of $100 \mathrm{~mm}$ is used and the reading for each age is taken as the mean of three specimens. On the other hand, prisms having the dimensions of $(100 \times 100 \times 500) \mathrm{mm}$ were used and the reading for each age is taken as the mean of the three specimens.

\section{Results and Discussion}

\subsection{Mix Proportions}

Due to the porous nature of OPA's particles, it is clear from Table 2 that the amount of water needed to achieve the required slump increases with the increase in replacement level of OPA. The Control mix needed the least amount of water were there was about $8.5 \mathrm{~kg}$ of extra water. On the other hand, the mix OPA65 with a replacement level of $65 \%$ of cement by OPA left out only $1.33 \mathrm{~kg}$ of water to achieve the desired slump.

\subsection{Compressive Strength}

The compressive strength results for all six mixes are listed in Table 4 below. All cubes were tested at a pace rate of $2.5 \mathrm{KN} / \mathrm{s}$ with an ELE testing machine that has a capacity of $3000 \mathrm{KN}$. The results show that two of the replacement levels, namely $25 \%$ and $35 \%$, have exhibited higher compressive strengths than that of the control mix at the age of 28 days. The $25 \%$ replacement showed 
a $9 \%$ increase to the control mix's compressive strength. While a $35 \%$ replacement exhibited $41 \%$ increase than the control mix's strength at 28 days. This can only be explained by the fact the OPA used, despite its large particle size, has a high content of $\left(\mathrm{SiO}_{2}\right)(66.6411 \%)$ enabling it to react with the Calcium Hydroxide $\left(\mathrm{Ca}(\mathrm{OH})_{2}\right)$ producing additional Calcium Silicate Hydrates $(\mathrm{C}-\mathrm{S}-\mathrm{H})$; hence, causing the improvement of the compressive strength [11].

However, mixes that exceeded a replacement level of 35\% showed lower compressive strengths. This phenomenon is interrelated to the fact that lower cement content will reduce the amount of Calcium Oxide $(\mathrm{CaO})$. For that reason, smaller amounts of Calcium Hydroxide $\left(\mathrm{Ca}(\mathrm{OH})_{2}\right)$ are produced which in turn are insufficient for all the silica to take part in the pozzolanic reaction creating Calcium Silicate Hydrates (C-S-H) which are responsible for the development of strength. This result agrees with findings of [16].

Table 4: Compressive strength results

\begin{tabular}{cccc}
\hline Mix & $\begin{array}{c}\text { 7days } \\
\text { (MPa) }\end{array}$ & 14days (MPa) & $\begin{array}{c}\text { 28days } \\
\text { (MPa) }\end{array}$ \\
\hline CC & 5.92 & 6.00 & 5.58 \\
OPA25 & 5.51 & 6.51 & 6.09 \\
OPA35 & 6.66 & 5.75 & 7.89 \\
OPA45 & 4.59 & 6.19 & 4.49 \\
OPA55 & 3.81 & 4.42 & 4.43 \\
OPA65 & 2.46 & 2.70 & 3.28 \\
\hline
\end{tabular}

\subsection{Splitting Tensile Strength}

The results for the splitting tensile strength for all six mixes are presented in Table 5. The cylinder specimens were tested at a pace rate of $0.94 \mathrm{KN} / \mathrm{s}$ with the same machine used for the compression test. The findings show a different trend than the compressive strength. The highest tensile strength is recorded at the age of 28 days for OPA25 exhibiting a tensile strength of $0.720 \mathrm{MPa}$ higher than that of the control mix by $8.3 \%$.

Table 5: Splitting tensile strength results

\begin{tabular}{cccc}
\hline Mix & 7 days (MPa) & 14 days (MPa) & 28 days (MPa) \\
\hline CC & 0.75 & 0.77 & 0.67 \\
OPA25 & 0.70 & 0.72 & 0.72 \\
OPA35 & 0.69 & 0.69 & 0.59 \\
OPA45 & 0.42 & 0.29 & 0.39 \\
OPA55 & 0.22 & 0.28 & 0.34 \\
OPA65 & 0.29 & 0.29 & 0.31 \\
\hline
\end{tabular}

\subsection{Flexural Strength}

Flexural strength specimens were tested using the same machine used for the prior tests. Prisms were tested at a pace rate of $0.200 \mathrm{KN} / \mathrm{s}$ using a 4 point flexural test. The results show that all replacement mixes suffer from lower flexural strengths when compared to the control mix. The nearest flexural reading was recorded for OPA25 having a reading of $1.802 \mathrm{MPa}$ by that obtaining $96 \%$ of the flexural strength exhibited by the control mix. Table 6 lists the results for the flexural strength of all mixes. 
Table 6: Flexural strength results

\begin{tabular}{cccc}
\hline Mix & $\mathbf{7}$ days $(\mathbf{M P a})$ & $\mathbf{1 4}$ days $(\mathbf{M P a})$ & $\mathbf{2 8}$ days $(\mathbf{M P a})$ \\
\hline CC & 1.62 & 2.12 & 1.87 \\
OPA25 & 1.45 & 1.29 & 1.80 \\
OPA35 & 1.87 & 1.61 & 0.98 \\
OPA45 & 0.74 & 0.92 & 0.78 \\
OPA55 & 0.56 & 0.56 & 0.68 \\
OPA65 & 0.52 & 0.67 & 0.52 \\
\hline
\end{tabular}

\section{Strength to Replacement Level Relationship}

The previous tests show that OPA when semi-processed (sieved through a $300 \mu \mathrm{m}$ sieve) with the help of a super-plasticizer can be a good pozzolanic material. Replacements of cement by the sieved only OPA can be done until 35\%. It is evident that both the $25 \%$ and $35 \%$ replacement levels excelled with its compressive strength. However, only the $25 \%$ replacement level showed higher splitting tensile strength than that of the control mix. On the other hand, flexural strength results showed that even at a $25 \%$ replacement flexural strength of about $96 \%$ of the control mix's flexural strength can be achieved. Fig. 1 shows the results for all mixes at the age of 28 days for the tests.

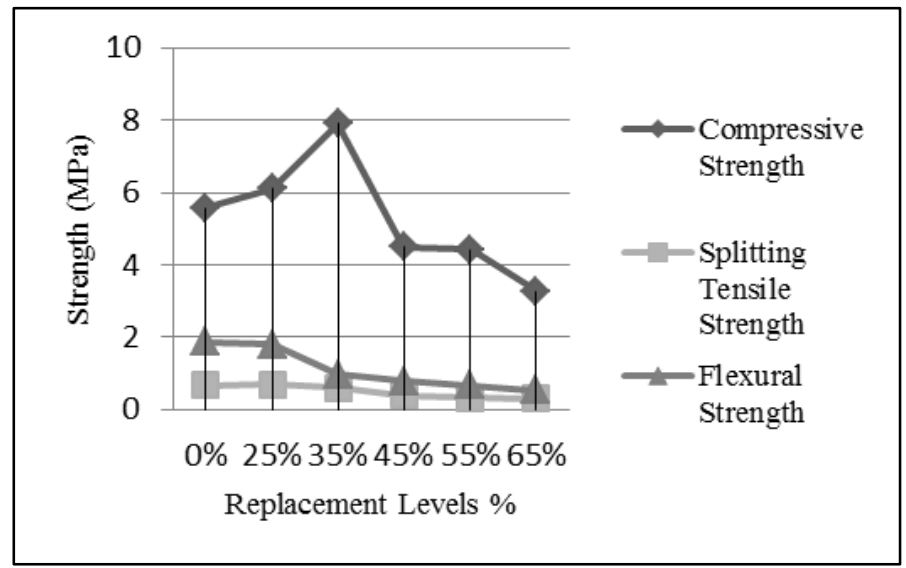

Figure 1: Results for all mixes at the age of 28 days for the tests.

\section{Conclusions}

1) When sieved OPA is used as a cement replacement, the increasing replacement levels will need more water to achieve the desired slump.

2) Replacement level of $25 \%$ showed good results in compressive strength, splitting tensile strength and flexural strength at the age of 28 days by obtaining a $109 \%, 108 \%$ and $96 \%$ of the control mix strengths, respectively.

3) When only Compressive strength is concerned, a 35\% replacement has shown good results by obtaining $141 \%$ of the control mix's compressive strength at the age of 28 days.

4) Increasing the replacement levels will decrease the strength of foam concrete. 


\section{References}

1. Jones, M.R. \& McCarthy, A.(2005), Behaviour and Assessment of Foamed Concrete for Construction Applications, in Dhir, RK, Newlands, MD \& McCarthy, A., Use of Foamed Concrete in Construction Proceedings of the International Conference Held at the University of Dundee, Scotland, UK on 5 July 2005, Thomas Telford, London, pp.61-88.

2. Narayanan, N. \& Ramamurthy, K. (2000), Structure and properties of aerated concrete: a review, Cement \& Concrete Composites, vol.22, pp.321-329.

3. Noordin, N. \& Awang, H. (2005), Lightweight foamed concrete in construction industry, International Conference on Construction and Real Estate Management ICCREM, $12^{\text {th }}-13^{\text {th }}$ December 2005, Penang, Malaysia, pp.1-6.

4. Siddique, R. \& Khan, M.I. (2011), Supplementary Cementing Materials, Springer, Berlin, pp.vii,.

5. Sata, V., Jaturapitakkul, C \& Kiattikomol, K, (2004), Utilization of palm oil fuel ash in highstrength concrete, Journal of Materials in Civil Engineering, vol.16, pp.1-6.

6. Foo, K.Y. \& Hameed, B.H. (2009a), Value-added utilization of oil palm ash: a superior recycling of this industrial agricultural waste, Journal of Hazardous Materials, vol.172, pp.523-531.

7. Foo, K.H \& Hameed, B.H (2009b), An overview of landfill leachate treatment via activate carbon adsorption process, Journal of HazardousMaterials, vol.171, pp.54-60.

8. Tay, J.H (1990) Ash from oil-palm waste as concrete material, Journal of Materials and Civil Engineering, vol.2, pp.1-12.

9. Tay, J.H. \&. Show, K.Y (1995), Use of Ash Derived from Oil-Palm Waste Incineration as a Cement Replacement Material, Resources, Conservation and Recycling, vol.13, pp.27-36.

10. Jaturapitakkul, K. Kiattikomol, W. Tangchirapat \& T. Saeting, (2007), Evaluation of the sulfate resistance of concrete containing palm oil fuel ash, Construction and Building Materials, vol.21, pp.1399-1405.

11. Sata, V., Jaturapitakkul, C. \& Kiattikomol, K. (2007), Influence of Pozzolan from Various ByProducts Materials on Mechanical Properties of High-Strength Concrete, Construction and Building Materials, vol.21, pp.1589-1598.

12. Johari, M.A.M., Zeyad, A.M , Bunnori, N.M. \& Ariffin, K.S. (2012), Engineering and Transport Properties of High-Strength Green Concrete Containing High Volume of Ultrafine Palm Oil Fuel Ash, Construction and Building Materials, vol.30, pp.281-288.

13. Chindaprasirt, P, Rukzon, S. \& Sirivivatnanon, V. (2008), Resistance to Chloride Penetration of Blended Portland Cement Mortar Containing Palm Oil Fuel Ash, Rice Husk Ash and Fly Ash, Construction and Building Materials, vol.22, pp.932-938.

14. Abdullah, K, Hussin, M.W., Zakaria, F, Muhamad, R. \& Abdul Hamid, Z. (2006), POFA: A Potential Partial Cement Replacement Material in Aerated Concrete, Proceedings of the $6^{\text {th }}$ Asian-Pacific Structural Engineering and Construction Conference (APSEC 2006) $5^{\text {th }}-6^{\text {th }}$ September 2006, Kuala Lumpur, Malaysia, pp.B-132-140.

15. Abdullah, K. \& Hussin, M. (2010), Fire Resistance Properties of Palm Oil Fuel Ash Cement Based Aerated Concrete, Concrete Research Letters, vol.1, pp.107-114.

16. Abdullah,K., Nasly, M.A., Hussin, M.W., Nordin, N. \& Zakaria, Z. (2010b), Properties of Aerated Concrete Containing Various Amount of Palm Oil Fuel Ash, Water Content and Binder Sand Ratio, $2^{\text {nd }}$ International Conference on Chemical, Biological and Environmental Engineering (ICBEE 2010) $2^{\text {nd }}-4^{\text {th }}$ November 2010, Cairo, Egypt, IEEE, pp.391-395.

17. ASTM C 618, (2001) Standard specification for coal fly ash and raw or calcined natural pozzolan for use as a mineral admixture in concrete.

18. Kearsley, E.P. \& Wainwright, P.J.(2001), The Effect of High Fly Ash Content on the Compressive Strength of Foamed Concrete, Cement and Concrete Research, vol.31, pp.105-112. 